\title{
University Students' Attitudes: Croatia Versus Turkey
}

Norman V. Schnurr, Robert Morris University, USA

Stanko Racic, Robert Morris University, USA

Tomislav Gelo, University of Zagreb, Croatia

\begin{abstract}
We surveyed Croatian and Turkish business school students, from universities emphasizing globalization, to analyze whether consideration for travel to the USA is affected by attitude toward their own country and the USA The results from comparing and contrasting differences between these countries and differences between males and females in each country - and their counterparts in the other country - may also give an outlook to future business relationships between the USA and these countries. Based on a t-test, Croatian students' ratings of the USA were significantly more positive, but there was no statistically significant difference in expectations to travel to the USA
\end{abstract}

Keywords: international business education; perception of home country and USA; gender differences

\section{INTRODUCTION}

¿ n a previous study (Schnurr, 2009), Turkish university students' attitudes toward their country and the USA were examined. Some faculty members were discussing how significantly different might the attitudes for students from different countries be about the USA. Could these differences have future implications about business relationships between these countries and the USA? What about the spread of globalization? One of the faculty members in the discussion was from Croatia. He was willing to contact a fellow who taught at Zagreb University. Agreement to conduct the survey with Croatian university students was made. Students from the two universities - one from the Turkey study and one in Croatia - were upper level $\left(3^{\text {rd }}\right.$ and $4^{\text {th }}$ year) students, business students, and from curriculum that stressed globalization. Using students from two countries that are considered quite diverse, but have had a history that literally and figuratively touched each other for some 400 years (the Ottoman Empire occupation of Eastern Europe - $15^{\text {th }}$ to $19^{\text {th }}$ century) might lead to some interesting results. Also, by comparing the results from the two countries, more insight might result from the first set of data. To illustrate the level of diversity between two countries, we present selected demographic data in Table 1. In addition to demographic characteristics, we also document the penetration of visitations from these two countries to the USA and the number of Americans who visited those two countries. The methodology and the findings from the study follow.

\section{METHODOLOGY}

A questionnaire was designed in English and then reverse translated into Turkish for Turkish university students. From March 30, 2007 to April 16, 2007, the survey was completed by 76 undergraduate students, out of 110 in the $3^{\text {rd }}$ and $4^{\text {th }}$ year, at Bahcesehir University in the Faculty (School) of Management.

Bahcesehir University was founded in 1998 as a non-profit to educate students using English as the primary language. The main campus sits directly on the Bosporus River on the European side in Besiktas, Istanbul, Turkey. The campus houses the six faculties (schools), including the Faculty of Management. The study's surveys were completed by juniors and seniors. Part of the mission of this department is to provide an education that will put students in touch with the global market and where Turkey can and will fit into this market. 
Table 1: Demographics And Penetration Of Visitation To Countries (000)

\begin{tabular}{|l|c|c|}
\hline \multicolumn{1}{|c|}{ Turkey } & Croatia \\
\hline Country Population $^{1}$ & $78,806(2009)$ & $4,489(2009)$ \\
\hline Religion $^{2}$ & $98 \%$ Muslim & $87 \%$ Catholic \\
\hline Literacy $^{2}$ & $87.4 \%$ & $98.5 \%$ \\
\hline Visits from USA $^{3}$ (number / \% of population) & $369(2008)$ & $158(2008)^{4}$ \\
\hline Total Visits to USA & $108 / .137 \%(2008)$ & 17 \\
\hline Students Visits to USA (number / \% of population) & $11 / .014 \%(2006)^{5}$ & $0.379 \%(2008)$ \\
\hline
\end{tabular}

${ }^{1}$ US Census Bureau, International Database and CIA Word Factbook, 2009.

${ }^{2}$ UNESCO.org, 2009.

${ }^{3}$ US Department of Commerce, International Trade Administration, Office of Travel and Tourism Industries www.tinet.ita.doc.gov

${ }^{4}$ Croatian National Institute of Statistics, Monthly Report for 2009, Number 1, Tourism. http://www.dzs.hr

${ }^{5}$ US Department of State, Bureau of Education and Cultural Affairs.

${ }^{6}$ Institute for the Development of Education

www.educationusa.state.gov/uploads/qB/pe/qBpegladbqXOxe8qjmWZsA/Croatia.pdf

The questionnaire for Croatian students was not translated as the English version was deemed acceptable. The survey was completed by 361 students, from about 1,000 students, in the $4^{\text {th }}$ year of study at the University of Zagreb's Faculty (School) of Economics and Business, Zagreb. Students from all departments of the Faculty (School) answered the questionnaire between November 25, 2008 and December 16, 2008.

The University of Zagreb, founded in 1669 , is the oldest and biggest university in Southeastern Europe. Through history, there were several changes in name, but never in mission - “... to educate experts in economics and business, especially in the current environment of internationalization and globalization." The university consists of 29 faculties, three art academies and the Center for Croatian Studies. The Faculty of Economics and Business started out as the School of Commerce and Transport in 1920.

The students were asked to complete a survey where all questions were on a scale of one (1) to ten (10) where a one (1) was a low or negative or unlikely rating and ten (10) was a high or positive or likely rating. Where they placed their rating from one to ten was based on their experiences or their perceptions. Most of the literature search indicated that students from both countries probably had little first-hand experience. This was based on numbers who had visited the USA or had experienced people from the USA visiting their country. The crossover is not high, so it is felt that most ratings were based on students' perceptions.

All data were edited, coded and inputted into SPSS. The responses to all questions for Croatian versus Turkish students were tested for significance using two-tailed student t-tests, assuming that samples are drawn from populations with different variances. Also, responses by male and female students for each country were tested to see if their counterparts in the other country responded differently.

\section{LIMITATION}

The Turkish study was conducted in March and April 2007. The Croatian study was November and December 2008. The time difference could have some influence on responses.

The election in the USA for president was held at the beginning of November 2008. Croatian students completed the survey following the election which might have some bearing on responses.

\section{SUMMARY OF FINDINGS}

Analysis of students' attitudes toward the USA and their own countries was conducted on the entire sample and two sub-samples based on the likelihood of traveling to the USA Students with high likelihood to travel to the USA were defined as those with answers 8, 9 and 10, and students with answers 1 through 5 were considered to have low likelihood of visiting the USA Findings based on sub-samples are presented following the analysis of the entire sample. 


\section{Significance Comparison Croatian Versus Turkish Students}

Both Turkish and Croatian students were more optimistic about their own country as a great place to live versus presently living in the USA This was more significant for the ratings of living in the USA Ten years from now where Turkish students (mean 4.63) gave significantly lower ratings than Croatian students (mean 5.86), with $\mathrm{T}$ $=4.10^{1}$.

In most other ratings of the USA, Croatian students were more positive than Turkish students. This was especially true in the ratings of USA's present leadership (Croatian and Turkish means of 7.40 and 3.43, respectively).

There were two statements that exhibited no differences: "USA is greatly influenced by religion" $(T=0.16)$ and "Expectations to travel to America" ( $\mathrm{T}=0.17)$.

Both Croatian and Turkish students felt the resolution of the Palestinian/Israeli conflict in the next two years had little hope (Turkish and Croatian means of 3.41 and 4.03) but were somewhat more optimistic for a resolution in five years. (Remember March 2007 for Turkish and November 2008 for Croatian students). The Turkish students gave very low ratings as to Iraq's war influence on USA's image (3.83 mean). Croatian student rating averaged $7.36\left(\mathrm{~T}=6.81^{2}\right)$.

When rating their own country the Croatian students were more optimistic and positive than Turkish students with one exception: "I am proud to be Turkish" (9.39 mean) and "I am proud to be Croatian" ( 8.82 mean) $\left(\mathrm{T}=3.07^{3}\right)$.

There was one other place that Turkish students gave higher ratings than their Croatian fellow students the chance of travel to an American University for a semester of study $\left(\mathrm{T}=2.55^{4}\right)$. However, neither set of students were overly optimistic (Tables A1 and A2 in the Appendix).

Croatian students gave high ratings to:

In 10 years, Croatia will be a great place to live

Croatia is greatly influenced by religion

Croatian people are friendly and likeable

Croatian people are artistic and creative

I am proud to be Croatian

USA's present leadership

USA is very open, free society

Turkish students gave high ratings to:

Turkey is greatly influenced by religion

Turkish people are friendly and likable

I am proud to be Turkish

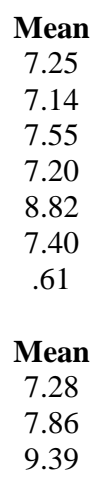

Croatian students were also asked about resolution of the problems in Bosnia and Kosovo in the next two and five years. They were slightly more optimistic than they had been over the Palestine and Israel conflict, but still not very optimistic. When examining the Bosnia and Kosovo problem influence on the image of USA and Croatia, the students felt that both countries' image was hurt by the problem, but were more negative about the impact on USA's image than on Croatia.

When asked the open-ended question, "Can you give at least one reason why people may not travel to America?", Croatian university students were most likely to indicate money and travel/expenses as the main reason

\footnotetext{
${ }^{1}$ Statistically significant at $1 \%$ level.

${ }^{2}$ Statistically significant at $1 \%$ level.

${ }^{3}$ Statistically significant at $1 \%$ level.

${ }^{4}$ Statistically significant at $5 \%$ level.
} 
followed by fear of terrorism and difficulties in obtaining a visa. Turkish students mentioned difficulties with getting a visa, especially after 9/11. Turkish students also cited worries about discrimination against Muslims in the USA after 9/11. Distance of travel was also given by some of the Turkish students.

\section{Croatian Male Responses Versus Female Responses}

Although in most cases the response was not significantly different, Croatian males tended to give slightly more positive ratings about their country than their female counterparts. As can be seen in Table 2 , males were significantly more positive (all at 5\% statistical level) for "In 10 years, Croatia will be a great place to live" and "I am proud to be Croatian." Croatian females gave a significantly more positive response to "Croatian people are hard working" and in rating of the USA's present leadership (again all at 5\% statistical level).

Females were more optimistic (although ratings were low) about resolution of the Palestine and Israel conflict than Croatian males, but females were less optimistic about the Bosnia and Kosovo conflict resolution. Both males and females were more optimistic for a resolution in five years for both conflicts (Tables A1 and A2 in the Appendix).

Table 2: Perception Of Male Versus Female Students In Croatia

\begin{tabular}{|l|c|c|c|c|c|c|c|c|}
\hline \multicolumn{1}{|c|}{ Question } & \multicolumn{3}{c|}{ Male Students } & \multicolumn{3}{c|}{ Female Students } & \multicolumn{2}{c|}{ Male - Female } \\
\cline { 2 - 10 } & $\mathbf{N}$ & Mean & SD & N & Mean & SD & Mean & t-statistic \\
\hline $\begin{array}{l}\text { In 10 years Croatia will be a great place to } \\
\text { live in }\end{array}$ & 74 & 7.80 & 2.15 & 287 & 7.11 & 1.92 & 0.69 & $2.51^{* *}$ \\
\hline Croatian people are hard working & 72 & 5.86 & 2.80 & 287 & 6.63 & 2.12 & -0.77 & $-2.17 * *$ \\
\hline I am proud to be Croatian & 72 & 9.19 & 1.36 & 286 & 8.73 & 1.74 & 0.47 & $2.45^{* *}$ \\
\hline USA's present leadership & 73 & 6.78 & 2.75 & 286 & 7.56 & 2.13 & -0.78 & $-2.25^{* *}$ \\
\hline
\end{tabular}

* Denotes statistical significance at $10 \%$ level.

** Denotes statistical significance at $5 \%$ level.

*** Denotes statistical significance at $1 \%$ level.

\section{Turkish Male Responses Versus Female Responses}

As was found with Croatian males versus females, results in Table 3 indicate that Turkish males tended to be more positive about their country than females and Turkish females were more positive in their ratings of the USA than their male counterparts. But the only question that showed a statistically significant difference at a 5\% level was the rating of "Turkey's present leadership" - the females' response was significantly lower (Tables A1 and A2 in the Appendix).

Table 3: Perception Of Male Versus Female Students In Turkey

\begin{tabular}{|c|c|c|c|c|c|c|c|c|}
\hline \multirow{2}{*}{ Question } & \multicolumn{3}{|c|}{ Male Students } & \multicolumn{3}{c|}{ Female Students } & \multicolumn{2}{c|}{ Male - Female } \\
\cline { 2 - 10 } & $\mathbf{N}$ & Mean & SD & N & Mean & SD & Mean & t-statistic \\
\hline Turkey's present leadership & 49 & 4.59 & 2.78 & 27 & 3.30 & 1.96 & 1.30 & $2.37 * *$ \\
\hline
\end{tabular}

* Denotes statistical significance at $10 \%$ level.

** $\quad$ Denotes statistical significance at $5 \%$ level.

*** Denotes statistical significance at $1 \%$ level.

\section{Croatian Males versus Turkish Males' Responses}

Croatian males were significantly more positive in their ratings of the USA/American people. This was especially true in the Turkish males rating of USA's present leadership (3.06) versus Croatian males (6.78) with T = $8.23^{5}$ and the Iraq war's influence on America's image. Turkish males gave an average rating of 3.35, while Croatian males had a 7.31 average $\left(T=6.81^{6}\right)$.

\footnotetext{
${ }^{5}$ Statistically significant at $1 \%$ level.

${ }^{6}$ Statistically significant at $1 \%$ level.
} 
Resolution of the Palestinian and Israeli conflict in the next two years had low ratings by males from both countries and were not significantly different $(T=0.70)$. There was more optimism for a resolution in five years by both sets of males, but again not significantly different $(T=0.07)$.

Males from Croatia tended to be more positive about their country - the open, free society - and their people being artistic, creative, and well-educated. Both sets of males were very proud of their nationality - Croatian (9.19 average) and Turkish (9.51 average), with no statistically significant differences at conventional levels $(\mathrm{T}=$ 1.47).

\section{Croatian Females Versus Turkish Females' Responses}

Although Turkish females (like Turkish versus Croatian males) were more pessimistic in their scoring of the USA than Croatian females, they were more similar in more statements. Like their male counterparts, females from each country were proud of their nationality - Croatian females (8.73 average) and Turkish females (9.19 average), with no significant differences $(\mathrm{T}=1.15)$.

There was no significant difference for:

USA is presently a great place to live

In 10 years, USA will be a great place to live

USA is greatly influenced by religion

American people are hard working

T-statistic
0.31
1.33
0.31
1.23

\section{RECAP OF FINDINGS}

Overall, the analysis found that Croatian students were more positive in their ratings of the USA than Turkish students. Furthermore, female students from both countries were more positive to the USA than their male counterparts, but the findings did not indicate significant differences in their likelihood to travel to the USA In an effort to better understand motives of the students, the analysis was repeated for a sub-sample of students with high expectations for travelling to the USA (answers 8, 9 and 10) and those with low expectation for travelling (answers 1 through 5).

Students with high expectations (answers 8, 9 and 10) of travelling to the USA from both countries were more similar in their various rankings of the USA. In only two ratings - USA's present leadership $(\mathrm{T}=7.42)$ and USA is a very open, free society $(\mathrm{T}=7.46)$ - were there significant differences (both at statistical $1 \%$ level) between Croatian and Turkish "high expectations" students.

When examining the differences between Turkish students who were very likely to travel to the USA (answers 8, 9 and 10) and those less likely (answers 1 through 5), reported in Table 4, there was significant difference in their ratings of the USA in five of the nine areas ranked, all at the $1 \%$ level.

Table 4: Differences Of Turkish Students' Perceptions About USA

\begin{tabular}{|c|c|c|c|c|c|c|c|c|}
\hline \multirow[t]{2}{*}{ Question } & \multicolumn{3}{|c|}{$\begin{array}{l}\text { Highly likely to } \\
\text { travel to USA }\end{array}$} & \multicolumn{3}{|c|}{$\begin{array}{c}\text { Less likely to travel } \\
\text { to USA }\end{array}$} & \multicolumn{2}{|c|}{ High - Less } \\
\hline & $\mathbf{N}$ & Mean & SD & $\mathbf{N}$ & Mean & SD & Mean & t-test \\
\hline USA is presently a great place to live in & 25 & 7.40 & 1.87 & 27 & 4.04 & 2.28 & 3.36 & $5.83 * * *$ \\
\hline In 10 years, USA will be a great place to live in & 22 & 6.36 & 1.99 & 27 & 3.52 & 2.36 & 2.85 & $4.58 * * *$ \\
\hline USA's present leadership & 25 & 4.36 & 2.29 & 27 & 3.04 & 2.53 & 1.32 & $1.98^{*}$ \\
\hline USA is a very open, free society & 23 & 5.43 & 1.83 & 26 & 3.62 & 2.32 & 1.82 & $3.07 * * *$ \\
\hline USA is greatly influenced by religion & 24 & 5.29 & 2.66 & 27 & 5.52 & 3.02 & -0.23 & -0.29 \\
\hline American people are friendly and likable & 25 & 6.04 & 2.26 & 27 & 3.85 & 2.09 & 2.19 & $3.61 * * *$ \\
\hline American people are artistic and creative & 25 & 6.00 & 2.18 & 26 & 4.19 & 2.08 & 1.81 & $3.03 * * *$ \\
\hline American people are well-educated & 25 & 6.16 & 2.10 & 27 & 5.89 & 1.58 & 0.27 & 0.52 \\
\hline American people are hard working & 25 & 6.00 & 2.04 & 27 & 5.67 & 1.94 & 0.33 & 0.60 \\
\hline
\end{tabular}

* Denotes statistical significance at $10 \%$ level.

** Denotes statistical significance at $5 \%$ level.

*** Denotes statistical significance at $1 \%$ level. 
Results in Table 5 indicate that Croatian students who were more likely to travel to the USA (answers 8, 9 and 10) and Croatian students less likely (answers 1 through 5) were significantly different in eight of the 9 areas rated about the USA (at the $1 \%$ level).

Table 5: Differences In Croatian Students' Perceptions About USA

\begin{tabular}{|c|c|c|c|c|c|c|c|c|}
\hline \multirow[t]{2}{*}{ Question } & \multicolumn{3}{|c|}{$\begin{array}{c}\text { Highly likely to } \\
\text { travel to USA }\end{array}$} & \multicolumn{3}{|c|}{$\begin{array}{c}\text { Less likely to travel } \\
\text { to USA }\end{array}$} & \multicolumn{2}{|c|}{ High - Less } \\
\hline & $\mathbf{N}$ & Mean & SD & $\mathbf{N}$ & Mean & SD & Mean & t-test \\
\hline USA is presently a great place to live in & 128 & 6.66 & 2.10 & 122 & 4.77 & 1.96 & 1.89 & $7.37 * * *$ \\
\hline In 10 years, USA will be a great place to live in & 130 & 6.86 & 2.12 & 122 & 4.96 & 2.19 & 1.90 & $7.00 * * *$ \\
\hline USA's present leadership & 129 & 8.04 & 2.16 & 121 & 6.72 & 2.60 & 1.32 & $4.36 * * *$ \\
\hline USA is a very open, free society & 130 & 8.48 & 1.68 & 121 & 6.92 & 2.22 & 1.57 & $6.27 * * *$ \\
\hline USA is greatly influenced by religion & 129 & 5.48 & 2.66 & 122 & 4.67 & 2.42 & 0.81 & $2.52 * *$ \\
\hline American people are friendly and likable & 129 & 6.74 & 2.00 & 121 & 5.34 & 2.07 & 1.41 & $5.45 * * *$ \\
\hline American people are artistic and creative & 129 & 6.95 & 1.73 & 121 & 5.94 & 2.16 & 1.00 & $4.03 * * *$ \\
\hline American people are well-educated & 129 & 6.40 & 2.20 & 121 & 5.10 & 2.49 & 1.30 & $4.35 * * *$ \\
\hline American people are hard working & 128 & 7.15 & 1.84 & 121 & 5.52 & 2.17 & 1.63 & $6.36^{* * *}$ \\
\hline
\end{tabular}

* Denotes statistical significance at $10 \%$ level.

** Denotes statistical significance at $5 \%$ level.

*** Denotes statistical significance at $1 \%$ level.

\section{FURTHER CONSIDERATIONS}

These students with a more positive attitude toward the USA seem to be more willing to participate in future relationships with the USA (significantly higher likelihood of travel to the USA), but the problem to help build a better or larger base of positive responses and understanding is still there.

Attitudes and perceptions toward the USA by students from Turkey have been undoubtedly formed from some of the historic events occurring between the two countries. As documented in Aylin Güney's article, "AntiAmericanism in Turkey: Past and Present", it started with the Cuban missile crisis. In the 1962 Cuban missile crisis, Turkey became the compromise (removal of missiles from Turkey) without consultation with the Turkish government. Then he goes on to discuss the "opium issue". In 1970, the USA placed sanctions of Turkey because it was determined that 80 percent of the heroin coming into the USA was from Turkey. Then Cyprus, the dispute between Turkey and Greece, resulted in further distancing of the USA and Turkey. There were several other issues causing dissent among Turks toward the USA, but the most telling and most influential on attitudes and perceptions of responding students was the invasion of Iraq in 2003. This put Turkey in a precarious position with the Kurds in northern Iraq and grave philosophically differentiating opinions with Washington.

The Bosnia and Kosovo problem might have some influence on Croatian student ratings of the USA, but their overall ratings were such that it did not appear to be a major issue.

An area that might be interesting to examine was that Turkish students on the ratings of 1 (low/unfavorable) to 10 (high/favorable) scale consistently were lower in their ratings on most statements than Croatian students. Does this mean that their thinking on what a "10" is might be different than a Croatian "10"?

The authors are pursuing extending the sampling of students to Serbia to discover if Serbian student findings might be similar or dissimilar to Turkish and Croatian findings. Also, the authors may redo the study in two to three years to see what - if anything - has changed.

While we have isolated the findings of how Croatian and Turkish university students felt about the issues rated, what has not been resolved is why the differences exist. More work needs to be completed to understand the causes of the differences. 
Is it? - levels of experience and knowledge about the USA

- timing of the two surveys

- the societal seeing of 1 to 10 differently

- a cultural cause influenced by different religions

- the importance of Kosovo and Bosnia or Iraq war

- or, perhaps all of the above or totally some other reason.

\section{AUTHOR INFORMATION}

Norman V. Schnurr, M.B.A., is a marketing consultant that has had many varied clients from banking, fast food chains, hospitals and professional sports teams.

Stanko Racic, Ph.D. Finance, research interests include Corporate and Multinational Finance, as well as Hospitality Industry. His papers were presented and published in proceedings of several academic conferences and published in academic journals including Journal of Financial Economics.

Tomislav Gelo, Ph.D. in Economics, specializes in Macroeconomics and Developmental Economics. His work was presented and published in proceedings of several academic conferences. His manuscripts were published in academic and professional journals.

\section{REFERENCES}

1. Aylin Güney, “Anti-Americanism in Turkey: Past and Present”, Middle Eastern Studies, Vol. 44, No. 3, 487, May 2008.

2. $\quad$ CIA World Factbook 2009

3. Croatian National Institute of Statistics, Monthly Report for 2009, Number 1, Tourism. http://www.dzs.hr

4. Institute for the Development of Education. http://www.educationusa.state.gov/uploads/qB/pe/qBpegladbqXOxe8qimWZsA/Croatia.pdf

5. $\quad$ Schnurr, N., S. Sezgin and G.G. Salman, "University Students' Perception of Two Countries", International Business and Economic Research Journal - June 2009, Volume 8, Number 6.

6. UNESCO UIS DATA/UNESCO Institute for statistics on website NationMaster.com

7. US Census Bureau, International Database

8. US Department of Commerce, ITA (International Trade Administration), Office of Travel and Tourism Industries www.tinet.ita.doc.gov

9. US Department of State, Bureau of Education and Cultural Affairs. 


\section{APPENDIX}

Table A1: Perceptions Of Croatian And Turkish Students About USA

\begin{tabular}{|c|c|c|c|c|c|c|c|c|c|}
\hline \multirow{2}{*}{\multicolumn{2}{|c|}{ Question }} & \multicolumn{3}{|c|}{ Croatian Students } & \multicolumn{3}{|c|}{ Turkish Students } & \multicolumn{2}{|c|}{ Croatia - Turkey } \\
\hline & & $\mathbf{N}$ & Mean & SD & $\mathbf{N}$ & Mean & SD & Mean & t-statistic \\
\hline \multirow{3}{*}{$\begin{array}{l}\text { In } 10 \text { years USA will be a } \\
\text { great place to live in }\end{array}$} & Sample & 361 & 5.86 & 2.20 & 73 & 4.63 & 2.37 & 1.23 & $4.10 * * *$ \\
\hline & Male & 74 & 6.16 & 2.57 & 46 & 4.33 & 2.32 & 1.84 & $4.04 * * *$ \\
\hline & Female & 287 & 5.79 & 2.09 & 27 & 5.15 & 2.41 & 0.64 & 1.33 \\
\hline \multirow{3}{*}{ USA's present leadership } & Sample & 359 & 7.40 & 2.29 & 76 & 3.43 & 2.29 & 3.97 & $13.73 * * *$ \\
\hline & Male & 73 & 6.78 & 2.75 & 49 & 3.06 & 2.22 & 3.72 & $8.23 * * *$ \\
\hline & Female & 286 & 7.56 & 2.13 & 27 & 4.11 & 2.29 & 3.45 & $7.51 * * *$ \\
\hline \multirow{3}{*}{$\begin{array}{l}\text { USA is a very open, free } \\
\text { society }\end{array}$} & Sample & 360 & 7.61 & 1.97 & 73 & 4.66 & 2.24 & 2.95 & $10.47 * * *$ \\
\hline & Male & 73 & 7.38 & 2.47 & 46 & 4.65 & 2.25 & 2.73 & $6.20 * * *$ \\
\hline & Female & 287 & 7.67 & 1.83 & 27 & 4.67 & 2.25 & 3.00 & $6.71 * * *$ \\
\hline \multirow{3}{*}{$\begin{array}{l}\text { American people are } \\
\text { friendly and likeable }\end{array}$} & Sample & 359 & 5.91 & 2.02 & 76 & 4.83 & 2.24 & 1.08 & $3.88 * * *$ \\
\hline & Male & 72 & 5.75 & 2.21 & 49 & 4.67 & 2.17 & 1.08 & $2.66 * * *$ \\
\hline & Female & 287 & 5.94 & 1.98 & 27 & 5.11 & 2.36 & 0.83 & $1.78 *$ \\
\hline \multirow{3}{*}{$\begin{array}{l}\text { American people are } \\
\text { artistic and creative }\end{array}$} & Sample & 359 & 6.35 & 1.96 & 75 & 5.07 & 2.23 & 1.29 & $4.63 * * *$ \\
\hline & Male & 72 & 5.94 & 2.43 & 48 & 4.96 & 2.45 & 0.99 & $2.17 * *$ \\
\hline & Female & 287 & 6.46 & 1.82 & 27 & 5.26 & 1.81 & 1.20 & $3.28 * * *$ \\
\hline \multirow{3}{*}{$\begin{array}{l}\text { American people are hard } \\
\text { working }\end{array}$} & Sample & 358 & 6.36 & 2.09 & 76 & 5.82 & 2.00 & 0.54 & $2.13 * *$ \\
\hline & Male & 71 & 6.28 & 2.23 & 49 & 5.76 & 2.13 & 0.53 & 1.31 \\
\hline & Female & 287 & 6.38 & 1.99 & 27 & 5.93 & 1.80 & 0.45 & 1.23 \\
\hline \multirow{3}{*}{$\begin{array}{l}\text { Resolution of the } \\
\text { Palestinian and Israel } \\
\text { conflict in the next two } \\
\text { years }\end{array}$} & Sample & 360 & 4.03 & 2.02 & 76 & 3.41 & 2.11 & 0.62 & $2.36 * *$ \\
\hline & Male & 74 & 3.66 & 2.20 & 49 & 3.37 & 2.32 & 0.29 & 0.70 \\
\hline & Female & 286 & 4.13 & 1.97 & 27 & 3.48 & 1.67 & 0.64 & $1.88 *$ \\
\hline \multirow{3}{*}{$\begin{array}{l}\text { Iraq war's influence on } \\
\text { USA's image }\end{array}$} & Sample & 359 & 7.36 & 2.70 & 76 & 3.83 & 3.50 & 3.53 & $8.29 * * *$ \\
\hline & Male & 74 & 7.31 & 2.93 & 49 & 3.35 & 3.30 & 3.96 & $6.81 * * *$ \\
\hline & Female & 285 & 7.38 & 2.64 & 27 & 4.70 & 3.75 & 2.67 & $3.62 * * *$ \\
\hline
\end{tabular}

* Denotes statistical significance at $10 \%$ level.

** Denotes statistical significance at $5 \%$ level.

*** Denotes statistical significance at $1 \%$ level. 
Table A2: Perceptions Of Croatian And Turkish Students About Their Own Country

\begin{tabular}{|c|c|c|c|c|c|c|c|c|c|}
\hline \multirow{2}{*}{\multicolumn{2}{|c|}{ Question }} & \multicolumn{3}{|c|}{ Croatian Students } & \multicolumn{3}{|c|}{ Turkish Students } & \multicolumn{2}{|c|}{ Croatia - Turkey } \\
\hline & & $\mathbf{N}$ & Mean & SD & $\mathbf{N}$ & Mean & SD & Mean & t-statistic \\
\hline \multirow{3}{*}{$\begin{array}{l}\text { My country is presently a } \\
\text { great place to live in }\end{array}$} & Sample & 361 & 6.80 & 2.00 & 76 & 5.76 & 2.43 & 1.03 & $3.46 * * *$ \\
\hline & Male & 74 & 7.19 & 2.16 & 49 & 5.98 & 2.50 & 1.21 & $2.77 * * *$ \\
\hline & Female & 287 & 6.69 & 1.95 & 27 & 5.37 & 2.29 & 1.32 & $2.90 * * *$ \\
\hline \multirow{3}{*}{$\begin{array}{l}\text { In } 10 \text { years my country will } \\
\text { be a great place to live in }\end{array}$} & Sample & 361 & 7.25 & 1.98 & 76 & 6.25 & 2.50 & 1.00 & $3.27 * * *$ \\
\hline & Male & 74 & 7.80 & 2.15 & 49 & 6.55 & 2.57 & 1.25 & $2.81 * * *$ \\
\hline & Female & 287 & 7.11 & 1.92 & 27 & 5.70 & 2.33 & 1.40 & $3.03 * * *$ \\
\hline \multirow{3}{*}{$\begin{array}{l}\text { My country is a very open, } \\
\text { free society }\end{array}$} & Sample & 358 & 5.69 & 2.24 & 76 & 3.57 & 2.06 & 2.12 & $8.03 * * *$ \\
\hline & Male & 73 & 6.16 & 2.42 & 49 & 3.82 & 2.24 & 2.35 & $5.49 * * *$ \\
\hline & Female & 285 & 5.57 & 2.18 & 27 & 3.11 & 1.63 & 2.46 & $7.26 * * *$ \\
\hline \multirow{3}{*}{$\begin{array}{l}\text { My people are artistic and } \\
\text { creative }\end{array}$} & Sample & 358 & 7.20 & 1.79 & 75 & 5.97 & 2.12 & 1.22 & $4.65 * * *$ \\
\hline & Male & 72 & 7.33 & 1.82 & 48 & 5.94 & 2.24 & 1.40 & $3.61 * * *$ \\
\hline & Female & 286 & 7.16 & 1.78 & 27 & 6.04 & 1.95 & 1.12 & $2.88 * * *$ \\
\hline \multirow{3}{*}{$\begin{array}{l}\text { My people are well- } \\
\text { educated }\end{array}$} & Sample & 360 & 6.59 & 2.09 & 76 & 4.39 & 2.05 & 2.19 & $8.44 * * *$ \\
\hline & Male & 73 & 6.41 & 2.48 & 49 & 4.39 & 2.14 & 2.02 & $4.80 * * *$ \\
\hline & Female & 287 & 6.63 & 1.99 & 27 & 4.41 & 1.93 & 2.23 & $5.73 * * *$ \\
\hline \multirow{3}{*}{$\begin{array}{l}\text { My people are hard } \\
\text { working }\end{array}$} & Sample & 359 & 6.47 & 2.29 & 76 & 5.64 & 2.27 & 0.83 & $2.88 * * *$ \\
\hline & Male & 72 & 5.86 & 2.80 & 49 & 5.63 & 2.53 & 0.23 & 0.47 \\
\hline & Female & 287 & 6.63 & 2.12 & 27 & 5.67 & 1.75 & 0.96 & $2.67 * * *$ \\
\hline \multirow{3}{*}{$\begin{array}{l}\text { I am proud of my } \\
\text { nationality }\end{array}$} & Sample & 358 & 8.82 & 1.68 & 76 & 9.39 & 1.43 & -0.57 & $-3.07 * * *$ \\
\hline & Male & 72 & 9.19 & 1.36 & 49 & 9.51 & 1.00 & -0.32 & -1.47 \\
\hline & Female & 286 & 8.73 & 1.74 & 27 & 9.19 & 2.00 & -0.46 & -1.15 \\
\hline \multirow{3}{*}{$\begin{array}{l}\text { The chance of travel to an } \\
\text { American University for a } \\
\text { semester of study }\end{array}$} & Sample & 359 & 3.73 & 2.61 & 76 & 4.67 & 2.98 & -0.94 & $-2.55 * *$ \\
\hline & Male & 74 & 4.14 & 2.97 & 49 & 4.73 & 2.96 & -0.6 & -1.1 \\
\hline & Female & 285 & 3.63 & 2.51 & 27 & 4.56 & 3.07 & -0.93 & -1.52 \\
\hline
\end{tabular}

* Denotes statistical significance at $10 \%$ level.

** Denotes statistical significance at $5 \%$ level.

*** Denotes statistical significance at $1 \%$ level. 
NOTES 